\title{
Cytotoxic, Virucidal, and Antiviral Activity of South American Plant and Algae Extracts
}

\author{
Paula Faral-Tello, ${ }^{1}$ Santiago Mirazo, ${ }^{1}$ Carmelo Dutra, ${ }^{2}$ Andrés Pérez, ${ }^{2}$ \\ Lucía Geis-Asteggiante, ${ }^{2}$ Sandra Frabasile, ${ }^{1}$ Elina Koncke, ${ }^{1}$ Danilo Davyt, ${ }^{2}$ \\ Lucía Cavallaro, ${ }^{3}$ Horacio Heinzen, ${ }^{2}$ and Juan Arbiza ${ }^{1}$ \\ ${ }^{1}$ Sección Virología, Facultad de Ciencias, Universidad de la República, 11400 Montevideo, Uruguay \\ ${ }^{2}$ Cátedra de Productos Naturales Facultad de Química, Universidad de la República, 11800 Montevideo, Uruguay \\ ${ }^{3}$ Cátedra de Virología, Facultad de Farmacia y Bioquimica, Universidad de Buenos Aires, C1113AAD Buenos Aires, Argentina
}

Correspondence should be addressed to Juan Arbiza, jarbiza@fcien.edu.uy

Received 12 December 2011; Accepted 8 February 2012

Academic Editors: A. Banerjee, S. Cuzzocrea, and A. Zakhartchouk

Copyright (C) 2012 Paula Faral-Tello et al. This is an open access article distributed under the Creative Commons Attribution License, which permits unrestricted use, distribution, and reproduction in any medium, provided the original work is properly cited.

\begin{abstract}
Herpes simplex virus type 1 (HSV-1) infection has a prevalence of $70 \%$ in the human population. Treatment is based on acyclovir, valacyclovir, and foscarnet, three drugs that share the same mechanism of action and of which resistant strains have been isolated from patients. In this aspect, innovative drug therapies are required. Natural products offer unlimited opportunities for the discovery of antiviral compounds. In this study, 28 extracts corresponding to 24 plant species and 4 alga species were assayed in vitro to detect antiviral activity against HSV-1. Six of the methanolic extracts inactivated viral particles by direct interaction and 14 presented antiviral activity when incubated with cells already infected. Most interesting antiviral activity values obtained are those of Limonium brasiliense, Psidium guajava, and Phyllanthus niruri, which inhibit HSV-1 replication in vitro with 50\% effective concentration $\left(\mathrm{EC}_{50}\right)$ values of 185,118 , and $60 \mu \mathrm{g} / \mathrm{mL}$, respectively. For these extracts toxicity values were calculated and therefore selectivity indexes (SI) obtained. Further characterization of the bioactive components of antiviral plants will pave the way for the discovery of new compounds against HSV-1.
\end{abstract}

\section{Introduction}

Herpes simplex virus type 1 (HSV-1), a member of the Herpesviridae family, is a double-stranded DNA virus, extremely widespread in the human population $[1,2]$ with prevalence ranging from 60 to more than $95 \%$ [3]. It is responsible for a broad range of disorders, including gingivostomatitis, keratoconjunctivitis, genital disease, and encephalitis [4], causing more severe illnesses in newborns and immunocompromised patients [5].

Several drugs, acyclovir, vidarabine, phosphonoformic acid, and other compounds including interferon, are used to treat HSV-associated diseases [6]. However, an increasing amount of drug-resistant strains have been isolated in the last few years, thus limiting the efficacy of these drugs [7] and enhancing the need for drugs that innovate in the viral targets or/and the mechanisms of action.
It is estimated that $40 \%$ of modern drugs derived from natural sources [8]. Ethnopharmacological knowledge and texts of traditional herbal medicine usage have been an important source of information and have shown to be very efficient in the identification of bioactive compounds, even when compared to the standard high volume random screening method [9]. South American flora has been explored for bioactive compounds with remarkable results, including the antioxidant properties of Achyrocline satureioides commonly known as "Marcela" [10], capability of Phyllanthus niruri of dissolving kidney and gall stones [11], and the Echinacea purpurea anti-influenza virus properties [12].

Standardized cultivation of viruses is a powerful approach for in vitro drug testing that includes the possibility of comparison with reference drugs. The aim of this study was to challenge extracts of a set of South American plants to inhibit HSV-1 replication in a mammalian cell culture model. 
For this, 28 ethanolic extracts corresponding to 24 plant and 4 alga species were prepared and assayed in vitro to detect selective antiviral activity. All species are found in Uruguayan soil and reports describing usage in traditional medicine exist for all of them. Moreover, some of the plants are specifically recommended to treat genital, throat, eyes, and mouth sores and itching.

\section{Materials and Methods}

2.1. Plant and Algae Material. The collection of all plant and algae species was made in their natural environment in southern Uruguay, except for Phyllanthus niruri that was bought from Botica del Señor SRL (Lot $N^{\circ} 3$-Int. 1/07). The identification of all materials was performed by Lic. Alonso Paz and M. J. Bassagoda from the Department of Pharmaceutics Botanic of Facultad de Química, Universidad de la República. Voucher specimens have been deposited at the herbarium of Facultad de Química, Universidad de la República.

2.2. Preparation of Extracts. To prepare all ethanolic extracts the plant material was dried and macerated for 48 hours in EtOH $: \mathrm{H}_{2} \mathrm{O}(70: 30 \mathrm{v} / \mathrm{v})$. The algae material was air-dried and processed in the same way as plants except for Grateloupia filicina, where $\mathrm{CHCL}_{3}: \mathrm{MeOH}(50: 50 \mathrm{v} / \mathrm{v})$ was used for maceration. The liquid fractions were freeze-dried and solubilized in DMSO to prepare stock and work solutions.

2.3. Cells, Virus, and Acyclovir. Vero cells (African green monkey kidney, ATCC number CCL-81) were cultured in DMEM GlutaMAX-1 (Gibco Invitrogen) supplemented with $10 \%$ fetal bovine serum (FBS) (Gibco Invitrogen), $100 \mu \mathrm{g} /$ $\mathrm{mL}$ Streptomycin, and $1000 \mathrm{U} / \mathrm{mL}$ penicillin and grown at $37^{\circ} \mathrm{C}$ in a $5 \% \mathrm{CO}_{2}$ humidified atmosphere. The cell line used in this work was Mycoplasma sp. free. HSV-1 strain F was provided by Dra. Lucía Cavallaro from Cátedra de Virología, Facultad de Farmacia y Bioquímica, Universidad de Buenos Aires, Argentina. Acyclovir was purchased from Laboratorio Libra (Virulax 250) and prepared to $1 \mathrm{mg} / \mathrm{mL}$ in sterile water.

2.4. Determination of MNCC and $C_{50}$. To evaluate the effect of the extracts on Vero cells viability, dilutions ranging from 1000 to $16 \mu \mathrm{g} / \mathrm{mL}$ were added on $85-95 \%$ confluent monolayers in 96-well culture plates. After 72 hours of incubation, the maximum noncytotoxic concentration (MNCC) for all extracts was determined by microscopic observation and $\mathrm{CC}_{50}$ (extract concentration that is toxic for half of the cells) was determined by the crystal violet uptake method. Briefly, cell monolayers were fixed and stained with a crystal violet $0.75 \%$ in $40 \%$ methanol solution and incubated for 15 minutes at $37^{\circ} \mathrm{C}$. Nonincorporated crystal violet dye was removed. Retained dye in the cells was solubilized with an acetic acid $20 \%$ solution, and the absorbance at $570 \mathrm{~nm}$ was measured in a microplate reader (Bio-Rad, Model 680).

2.5. Screening of Antiviral Activity by Cytopathic Effect Reduction Assay. Primary antiviral screening test was conducted by cytopathic effect (CPE) reduction assay, which involves the protection of viral-caused lysis of Vero cells by extracts. Briefly, in 96-well culture plate, $5 \times 10^{4} \mathrm{UFP} / \mathrm{mL}$ of HSV- 1 was inoculated on Vero cells. After 1 hour of adsorption at $37^{\circ} \mathrm{C}$ in a $5 \% \mathrm{CO}_{2}$ humidified atmosphere, cells were washed with phosphate buffer saline (PBS) and 2-fold serial dilutions of the correspondent extract beginning at the MNCC were added. Cytotoxicity and cell controls were included. After 72 hours of incubation at $37^{\circ} \mathrm{C}$ in a $5 \% \mathrm{CO}_{2}$ humidified atmosphere, cells were fixed and stained as described in Section 2.4. The antiherpetic activity of the extracts was evaluated by direct observation of CPE reduction.

2.6. Determination of $E C_{50}$ by Plaque Reduction Assay. To determine the effective concentration that inhibited $50 \%$ of plaque forming units (PFUs) $\left(\mathrm{EC}_{50}\right)$ a standard plaque reduction assay was conducted. Briefly, Vero cells monolayers grown in 48-well culture plates were infected with $100 \mathrm{PFU}$ of HSV-1. After 1 hour of adsorption at $37^{\circ} \mathrm{C}$ in a $5 \% \mathrm{CO}_{2}$ humidified atmosphere the cells were rinsed with $\mathrm{PBS}$. Twofold serial dilutions of the correspondent extract (beginning from the MNCC) in medium containing 2\% FBS and $0.8 \%$ methylcellulose were added. Each concentration was tested in duplicate. Infected cultures were incubated for $48 \mathrm{~h}$ at $37^{\circ} \mathrm{C}$ in a $5 \% \mathrm{CO}_{2}$ humidified atmosphere. Cells were fixed and stained as described (see above). Plaques were counted and viral title expressed as PFU/well. Viral, cellular, and cytotoxic controls were performed in each assay. Acyclovir was included as a positive inhibition control.

2.7. Virucidal Activity Assay. To evaluate the presence of virucidal activity, direct inactivation of HSV-1 by the extracts was tested. To assay virucidal activity, a $5 \times 10^{9} \mathrm{UFP} / \mathrm{mL}$ viral inoculum was mixed with extracts at three serial concentrations (MNCC, MNCC/2, and MNCC/4) and incubated at room temperature for 1 hour. After that, viral inoculum was diluted in medium supplemented with $2 \%$ FBS to a 500 UFP/ $\mathrm{mL}$ concentration. Surviving infectious viral particles were measured by standard plaque reduction assaywith respect to the control in which virus was mixed with medium supplemented with 2\% FBS. Cell controls were included. Extract was considered positive when it inactivated $\geq 90 \%$ of the viral particles with respect to a control.

2.8. Data Analysis. $\mathrm{CC}_{50}$ and $\mathrm{EC}_{50}$ for each extract were obtained from dose-effect curves (data not shown). The values correspond to the average and standard deviation of three independent assays with at least 5 concentrations within the inhibitory range. The selectivity index (IS) is defined as $\mathrm{CC}_{50} / \mathrm{EC}_{50}$.

\section{Results}

Among the 27 extracts tested only 16 plant species presented anti-HSV-1 activity. MNCC, $\mathrm{EC}_{50}$, and virucidal activity values obtained for each extract are showed in Table 1. No antiviral activity was detected in the algae extracts. Extracts with anti-HSV-1 activity were also tested for virucidal activity. 
TABLE 1: Antiviral and virucidal activity of each plant and algae species.

\begin{tabular}{|c|c|c|c|c|}
\hline Species & $\operatorname{MNCC}^{\mathrm{a}}(\mu \mathrm{g} / \mathrm{mL})$ & Antiviral activity & $\mathrm{EC}_{50}^{\mathrm{b}}(\mu \mathrm{g} / \mathrm{mL})$ & Virucidal activity (\%) \\
\hline \multicolumn{5}{|l|}{ Plants } \\
\hline Achyrocline satureioides & 2500 & + & 380 & $<90$ \\
\hline Apium leptophyllum & 5000 & - & ND & ND \\
\hline Bauhinia candicans & 1250 & + & 1060 & 85 \\
\hline Chenopodium ambrosioides & 2500 & + & 920 & 90 \\
\hline Conyza bonariensis & 630 & - & ND & ND \\
\hline Eryngium pandanifolium & 1250 & - & ND & ND \\
\hline Heimia salicifolia & 1250 & - & ND & ND \\
\hline Ibicella lutea & 1250 & - & ND & ND \\
\hline Jaborosa runcinnata & 1250 & - & ND & ND \\
\hline Lentinus edulis & 5000 & - & ND & ND \\
\hline Limonium brasiliense & 500 & + & 185 & 99 \\
\hline Margyricarpus pinnatus & 1250 & + & 320 & 95 \\
\hline Phyllanthus niruri & 120 & + & 60 & 39 \\
\hline Polygonum punctatum & 1250 & + & 1230 & $<90$ \\
\hline Psidium incanum & 250 & + & 118 & 20 \\
\hline Psidium luridum & 310 & + & 1500 & 88 \\
\hline Schinus molle & 630 & + & 50 & $<90$ \\
\hline Salvia guaranitica & 250 & - & ND & ND \\
\hline Sesbania punicea & 1250 & + & 1100 & $<90$ \\
\hline Smilax gracilis & 2500 & + & 470 & 90 \\
\hline Sommerfeltia spinulosa & 1250 & - & ND & ND \\
\hline Tillandsia aeranthos & 2500 & + & 530 & 93 \\
\hline Tillandsia usneoides & 1250 & + & 470 & 91 \\
\hline Xanthium spinosum & 1250 & - & ND & $\mathrm{ND}$ \\
\hline \multicolumn{5}{|l|}{ Algae } \\
\hline Corallina officinalis & 630 & - & ND & ND \\
\hline Chondria atropurpurea & 1250 & - & ND & ND \\
\hline Grateloupia filicina & 2500 & - & ND & ND \\
\hline Hypnea musciformis & 630 & - & ND & ND \\
\hline Acyclovir & 120 & + & 45 & 99 \\
\hline
\end{tabular}

${ }^{a}$ Maximum noncytotoxic concentration.

${ }^{\mathrm{b}}$ Effective concentration 50\%.

N/D: not determined.

+ Positive antiviral activity in the screening assay.

In this experiment 6 of them showed virucidal values $\geq 90 \%$ of PFU reduction.

With respect to antiviral activity and $\mathrm{EC}_{50}$ determination, Psidium guajava, Phyllanthus niruri, and Limonium brasiliense extracts had the highest values: 118,60 , and $185 \mu \mathrm{g} / \mathrm{mL}$, respectively. In addition, for the three extracts $\mathrm{CC}_{50}$ values were determined in mammalian cells and SI was calculated in each case. P. niruri presented the highest SI (42.37), followed by P. guajava (14.89). L. brasiliense showed an SI of 4.58. CC 50 and SI values are shown in Table 2.

\section{Discussion and Conclusions}

The limited efficacy of the current treatment of HSV-1 infection enhances the need for novel therapies that include drugs with innovative viral targets and/or mechanisms of action. Since approximately $40 \%$ of modern drugs derived from natural sources and Ethnopharmacological knowledge
TABLE 2: $\mathrm{CC}_{50}$ and SI calculated for each anti-HSV-1 extract.

\begin{tabular}{lcc}
\hline Plant species & $\mathrm{CC}_{50}{ }^{\mathrm{a}}(\mu \mathrm{g} / \mathrm{mL})$ & $\mathrm{SI}^{\mathrm{b}}$ \\
\hline Psidium incanum & 1756 & 14.89 \\
Phyllanthus niruri & 2542 & 42.37 \\
Limonium brasiliense & 848 & 4.58 \\
Acyclovir & 3190 & 70.9 \\
\hline
\end{tabular}

${ }^{a}$ Cytotoxic concentration 50\%.

${ }^{b}$ Selectivity index. Ratio $\mathrm{CC}_{50} / \mathrm{EC}_{50}$.

has been an important source of information for the identification of bioactive compounds, we conducted this investigation with the aim to identify natural sources of compounds that could be potentially included in a formulation to be used in therapy against HSV-1.

This work shows that ethanolic extracts of 16 plant species exhibit in vitro antiherpetic activity. The fact that $60 \%$ 
of all the plants assayed resulted positive demonstrates once again that traditional knowledge of medicinal plant usage is an efficient way of identifying biological and particularly antimicrobial activity. Half of the 16 positive plants showed $\mathrm{EC}_{50}$ values below $500 \mu \mathrm{g} / \mathrm{mL}$, about ten times greater than that of acyclovir, which is a purified compound. Among these, P. niruri, Psidium incanum, and L. brasiliense showed the highest anti-HSV-1 activity as was determined in plaque reduction assay.

It is important to emphasize that the value obtained for P. niruri $\left(\mathrm{EC}_{50}=60 \mu \mathrm{g} / \mathrm{mL}\right)$ clearly correlates with its traditional use $[13,14]$. In fact, this species is used to treat skin ulcers, sores, swelling, and itchiness of the skin [15] and other several illnesses including kidney and gall stones [9], jaundice, gonorrhea, and diabetes [16]. It also has been tested for antiviral activity against influenza [17], hepatitis B [18-20], and human immunodeficiency virus (HIV) [16]. Our results are in accordance with previous reports of antiherpetic activity of several species of the Phyllanthus genera [21-24]. With respect to $P$. guajava and L. brasiliense, there is no data about their antiherpetic activity. In fact, this is the first report demonstrating the inhibitory effect of HSV-1 replication in vitro of these plants. Remarkably, the three plant species have been widely used in traditional medicine by South American ancient populations for the treatment of several illnesses $[13,25]$.

Since an antiviral compound should combine the highest effectiveness with the lowest cytotoxicity, it was important to evaluate the SI in order to determine the potential application of extract-derived compounds as antiviral agents. $P$. niruri has the highest SI resulting of a low $\mathrm{CC}_{50}$ value combined with a high affectivity.

L. brasiliense has an encouraging value of antiviral effectivity $\left(\mathrm{EC}_{50}=185 \mu \mathrm{g} / \mathrm{mL}\right)$, but the ethanolic extract of this plant is also highly toxic resulting in an SI of 4.58. Since ethanolic extracts are complex and heterogeneous and compounds of different chemical origin are present, it might be possible to separate toxic molecules from those responsible of the antiviral activity. For these, further studies with purification fractions of the extract should be carried out.

On the other hand, it was important to differentiate direct viral particle inactivation from antiviral activity. In fact, virucidal activity might eclipse antiviral activity if tests of direct inactivation of viral particles are not performed. In our study, 6 plant extracts presented a positive activity (plaque reduction higher $\geq 90 \%$ ). For this extracts one might assume that part of their activity relies on direct inactivation of the viral particles after virus adsorption and that this might also be occurring in the antiviral assay. However, this is not the case for extracts that combine low or no virucidal activity with positive antiviral activity (i.e., $P$. niruri, $P$. incanum, Apium leptophyllum, and Conyza bonariensis). For these antiHSV-1 species another mechanism of action should exist since they act in postabsorption steps of the viral cycle.

The results presented here justify further investigation of the extracts by bioguided fractionation procedures that hopefully will allow to identify active molecule(s) involved in anti-HSV-1 activity. If purified compounds with at least the antiviral values showed here are identified, this will turn them into candidates for in vivo trials and future antiherpetic formulations.

\section{Acknowledgments}

This work was supported by grants from the Programa de Desarrollo Tecnológico (PDT 75/07), Dirección de Innovación Ciencia y Tecnología para el Desarrollo (DICyT), and CONICYT-BID (321), Ministerio de Educación y Cultura Montevideo, Uruguay. P. Faral-Tello's fellowship was supported by grants of Agencia Nacional de Investigación e Innovacion (ANII) through its program Sistema Nacional de Becas (BE_INI_2008_108). P. Faral-Tello's and S. Mirazo contributed equally to this work. The authors would like to thank Agencia Nacional de Investigación de Innovación (ANII) and Programa de Desarrollo de Ciencias Básicas (PEDECIBA).

\section{References}

[1] J. S. Smith and N. J. Robinson, "Age-specific prevalence of infection with herpes simplex virus types 2 and 1: a global review," Journal of Infectious Diseases, vol. 186, no. 1, pp. S3S28, 2002.

[2] J. Akhtar and D. Shukla, "Viral entry mechanisms: cellular and viral mediators of herpes simplex virus entry," FEBS Journal, vol. 276, no. 24, pp. 7228-7236, 2009.

[3] A. L. Cunningham and Z. Mikloska, "The holy grail: immune control of human herpes simplex virus infection and disease," Herpes, vol. 8, no. 1, pp. 6A-10A, 2001.

[4] R. J. Whitley, D. W. Kimberlin, and B. Roizman, "Herpes simplex viruses," Clinical Infectious Diseases, vol. 26, no. 3, pp. 541-555, 1998.

[5] G. Kleymann, "Agents and strategies in development for improved management of herpes simplex virus infection and disease," Expert Opinion on Investigational Drugs, vol. 14, no. 2, pp. 135-161, 2005.

[6] K. A. Cassady and R. J. Whitley, "New therapeutic approaches to the alphaherpesvirus infections," Journal of Antimicrobial Chemotherapy, vol. 39, no. 2, pp. 119-128, 1997.

[7] F. Nugier, J. N. Colin, M. Aymard, and M. Langlois, "Occurrence and characterization of acyclovir-resistant herpes simplex virus isolates: report on a two-year sensitivity screening survey," Journal of Medical Virology, vol. 36, no. 1, pp. 1-12, 1992.

[8] S. A. A. Jassim and M. A. Naji, "Novel antiviral agents: a medicinal plant perspective," Journal of Applied Microbiology, vol. 95, no. 3, pp. 412-427, 2003.

[9] J. E. Williams, "Review of antiviral and immunomodulating properties of plants of the peruvian rainforest with a particular emphasis on uña de gato and sangre de grado," Alternative Medicine Review, vol. 6, no. 6, pp. 567-579, 2001.

[10] C. Desmarchelier, J. Coussio, and G. Ciccia, "Antioxidant and free radical scavenging effects in extracts of the medicinal herb Achyrocline satureioides (Lam.) DC. ("marcela")," Brazilian Journal of Medical and Biological Research, vol. 31, no. 9, pp. 1163-1170, 1998.

[11] A. M. Freitas, N. Schor, and M. A. Boim, "The effect of Phyllanthus niruri on urinary inhibitors of calcium oxalate crystallization and other factors associated with renal stone formation," BJU International, vol. 89, no. 9, pp. 829-834, 2002.

[12] A. Wacker and W. Hilbig, "Virus-inhibition by echinacea purpurea (author's transl)," Planta Medica, vol. 33, no. 1, pp. 89102, 1978. 
[13] E. Alonso Paz and F. F. Yuyos, Uso racional de las plantas medicinales, Montevideo, Uruguay, 1992.

[14] J. Alonso, Plantas Medicinales Autóctonas de la Argentina, Bases Científicas para su aplicación en Atención Primaria de la Salud, Buenos Aires, Argentina, 2005.

[15] Bharatiya, Selected Medicinal Plants of India, Tata Press, Mumbai, India, 1992.

[16] A. D. Naik and A. R. Juvekar, "Effects of alkaloidal extract of Phyllanthus niruri on HIV replication," Indian Journal of Medical Sciences, vol. 57, no. 9, pp. 387-393, 2003.

[17] J. E. Forero, L. Avila, N. Taborda et al., "In vitro anti-influenza screening of several Euphorbiaceae species: structure of a bioactive Cyanoglucoside from Codiaeum variegatum," Phytochemistry, vol. 69, no. 16, pp. 2815-2819, 2008.

[18] X. Cui, Y. Wang, N. Kokudo, D. Fang, and W. Tang, "Traditional Chinese medicine and related active compounds against hepatitis B virus infection," Bioscience Trends, vol. 4, no. 2, pp. 39-47, 2010.

[19] Z. Liu, X. Fu, N. Zhang, G. Zhang, and D. Liu, "The inhibitory effect of Chinese herb Phyllanthus on hepatitis B virus in vitro," Zhonghua Shi Yan He Lin Chuang Bing Du Xue Za Zhi, vol. 11, no. 3, pp. 282-285, 1997.

[20] P. S. Venkateswaran, I. Millman, and B. S. Blumberg, "Effects of an extract from Phyllanthus niruri on hepatitis B and woodchuck hepatitis viruses: In vitro and in vivo studies," Proceedings of the National Academy of Sciences of the United States of America, vol. 84, no. 1, pp. 274-278, 1987.

[21] J. A. Fernández Romero, G. Del Barrio Alonso, B. R. Álvarez, Y. Gutiérrez, V. S. Valdés, and F. Parra, "In vitro antiviral activity of Phyllanthus orbicularis extracts against herpes simplex virus type 1," Phytotherapy Research, vol. 17, no. 8, pp. 980982, 2003.

[22] D. Arboleda, A. López, and J. E. Forero, "Evaluacion de La Actividad Antiviral in vitro de cuatro extractos de las especies Caryodendron orinocense y Phyllanthus niruri de La familia Euphorbiacea contra los virus Herpes Bovino Tipo 1 y Herpes Simplex Tipo 2," Revista de la Facultad de Química Farmacéutica, vol. 14, pp. 55-60, 2007.

[23] Y. Xiang et al., "In vitro Anti-Herpes Simplex Virus Activity of 1,2,4,6-Tetra-O-galloyl-beta-d-glucose from Phyllanthus emblica L. (Euphorbiaceae)," Phytotherapy Research, vol. 5, no. 7, pp. 975-982, 2011.

[24] C. M. Yang, H. Y. Cheng, T. C. Lin, L. C. Chiang, and C. C. Lin, "Acetone, ethanol and methanol extracts of Phyllanthus urinaria inhibit HSV-2 infection in vitro," Antiviral Research, vol. 67, no. 1, pp. 24-30, 2005.

[25] E. L Ratera, Plantas de la flora Argentina empleadas en medicina popular, Buenos Aires, Argentina, 1980. 

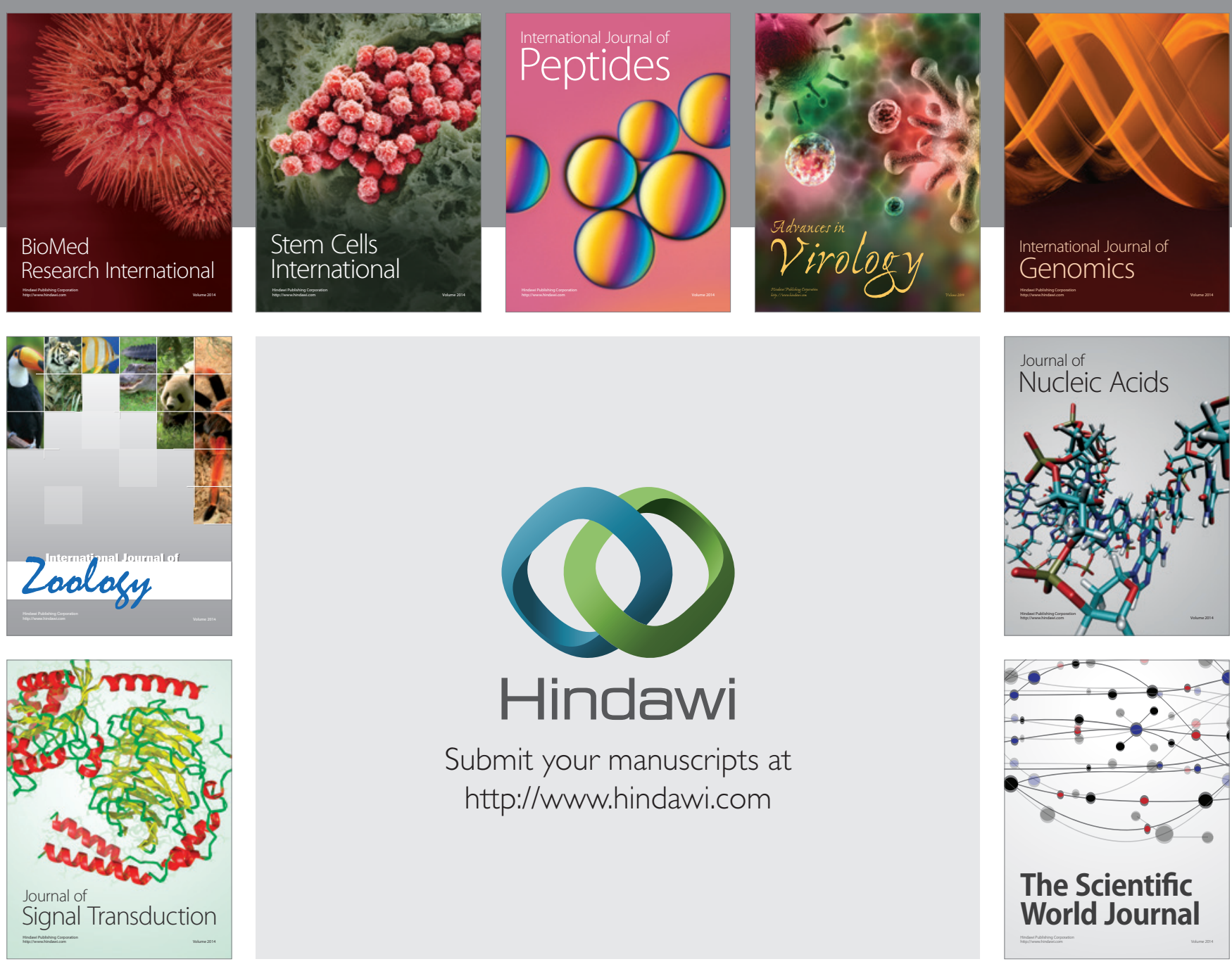

Submit your manuscripts at

http://www.hindawi.com
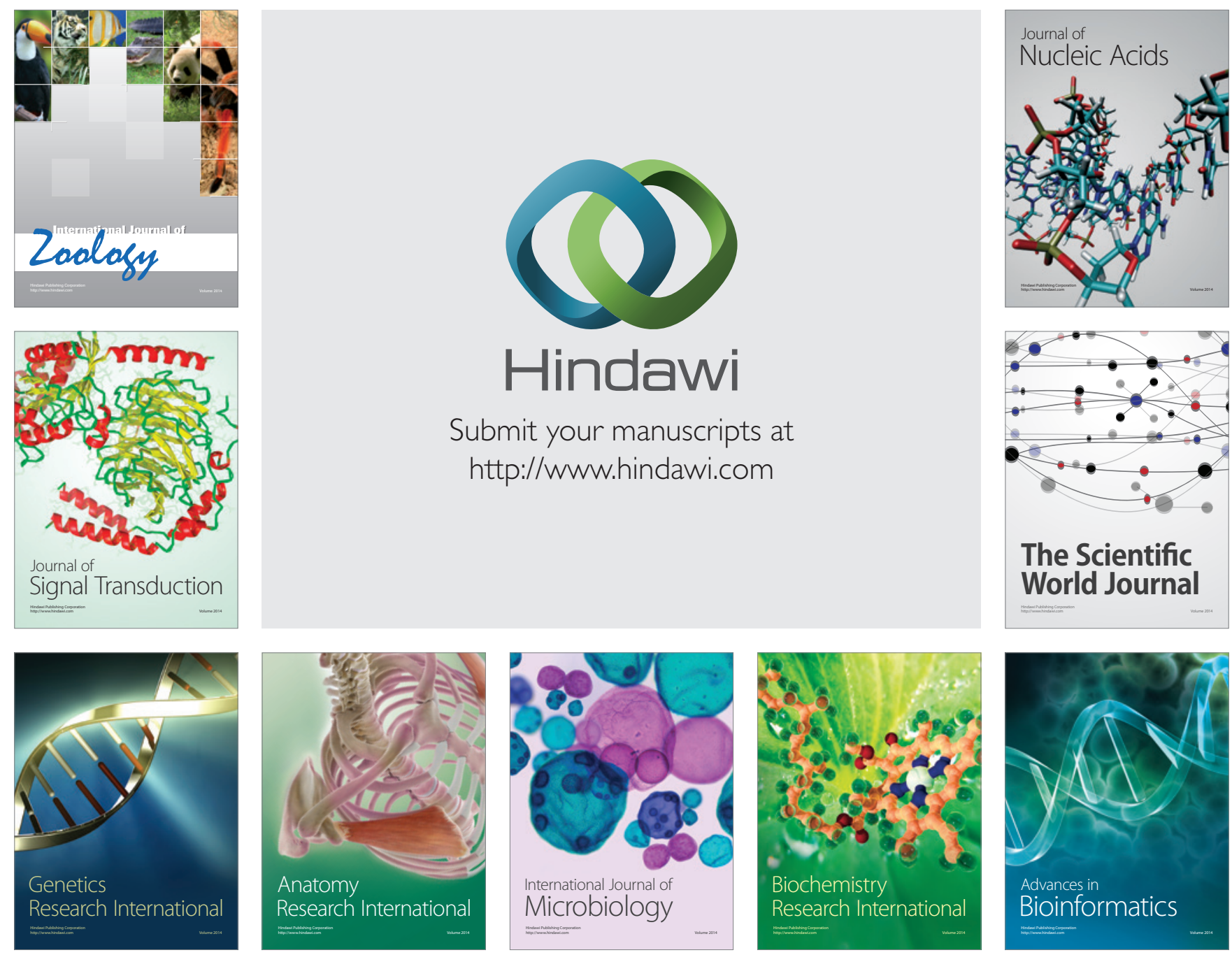

The Scientific World Journal
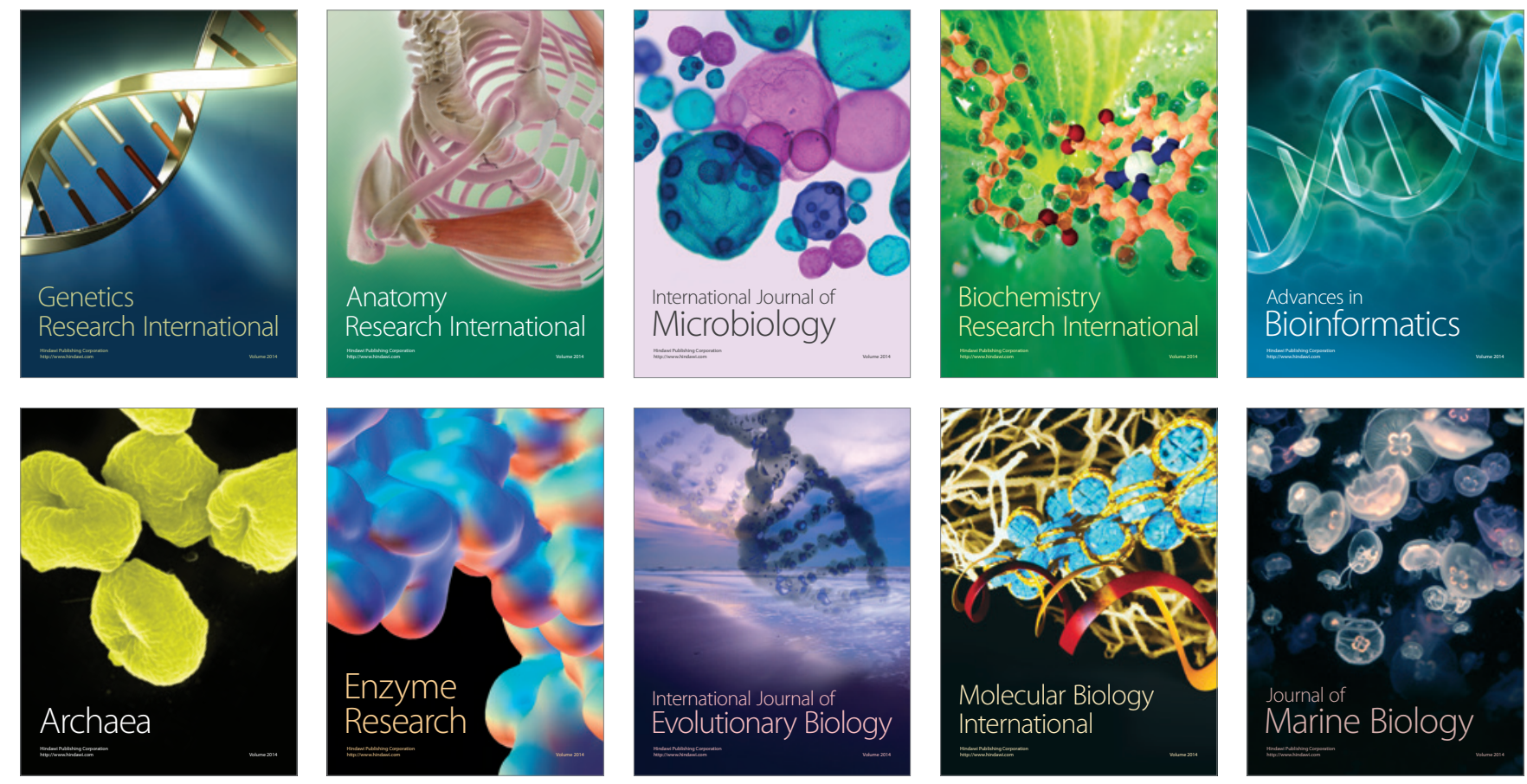